\title{
Ürün Yerleştirme ve Editoryal İçerik İle İlgili Artan Kaygılar: Türkiye'de Televizyon Draması Sektörü Örneği
}

\author{
Yrd. Doç. Dr. Selin TÜZÜN ATEŞALP \\ Ar. Gör. Dr. Babacan TAŞDEMIR
}

marmara üniversitesi iletişim fakültesi selintuzun@gmail.com akdeniz üniversitesi güzel sanatlar fakültesi babacantasdemir@akdeniz.edu.tr

\begin{abstract}
Product Placement and Growing Concerns as to Editorial Content: The Case of Television Drama Sector in Turkey

The study provides an assessment of the growing tension between product placement, an advertising application whose importance has been increasing for commercial TV, and noncommercial, cultural dimension of broadcasting. Broadly, 'product placement' is a technique of advertising which is based on references to or inclusions of a product or a brand within a program flow. In this sense, it is an advertising technique which is very hard to distinguish from surreptitious advertising and until very recently it has, therefore, stayed as a 'taboo' in many countries due to the reason that it would breach the principle of 'separation between advertisement and editorial content'. Yet, this stance has lost its ground very rapidly in the recent years and new regulations to 'legitimize' product placement have been adopted by many governments. In parallel with the amendments in European Union's (EU) legislation, a new code in Turkey (Code 6112) was adopted in 2011 to lift the ban on product placement applications. Following this amendment, product placement has become a way of advertising employed at an increasing scale and a growing source of revenue
\end{abstract}


for Turkey's media industry. In the scope of study, the amendment process behind the legitimation of product placement is assessed from a critical point of view. Then, a series of interviews with professionals from Turkey's media industry, especially from the TV drama series sector are conducted to understand concrete developments fueling concerns as to the editorial content. This paper argues that product placement practices have brought about the emergence of a market environment, in which the principle of 'separation between advertisement and editorial content' is damaged more than ever.

keywords: product placement, editorial content, television dramas, rtük, surreptitious advertising

\section{Résumé}

\section{Le placement de produit et les préoccupations croissantes concernant le contenu editorial: Le cas du secteur de séries télévisées en Turquie}

Cette étude fournit une discussion sur la tension croissante entre le placement de produit, une forme de publicité dont l'importance augmente pour la télévision commerciale ainsi que pour la dimension non-commerciale culturelle des médias audiovisuels. D'une façon générale, "le placement de produit " est une technique de communication commerciale consistant à inclure un produit ou une marque ou à y faire référence, en l'insérant dans le flux d'un programme. En ce sens, il s'agit d'une technique de publicité très difficile à distinguer de la publicité clandestine et par conséquent, jusqu'à très récemment, elle était considérée comme un "tabou» dans de nombreux pays pour la raison qu'il serait un moyen de violer le principe de "la séparation entre la publicité et le contenu éditorial ". Pourtant, dans ces dernières années, cette approche a perdu très rapidement sa justification et de nouvelles réglementations ont été adoptées par de nombreux gouvernements pour "légitimer" le placement de produit. En parallèle avec les modifications dans la législation de l'Union européenne (UE), un nouveau code (code 6112) a été adopté en Turquie en 2011 afin de lever l'interdiction sur le placement de produit. Suite à cette modification, le placement de produit est devenu un moyen de publicité effectué à une échelle croissante et une source de revenus pour l'industrie des médias en Turquie. Dans le cadre de cette étude, le processus de modification concernant la légitimation du placement de produit est examiné à partir d'un point de vue critique. Une série d'entretiens avec des professionnels -en particulier du secteur de séries télévisées- de l'industrie des médias turques, a été effectuée pour comprendre les évolutions concrètes qui renforcent les craintes concernant le contenu éditorial. Cet article soutient l'idée que les pratiques du placement de produits 
ont entraîné l'émergence de conditions liées à l'économie de marché, dans lesquelles le principe de "la séparation entre la publicité et le contenu éditorial " est endommagé plus que jamais.

mots-clés : le placement de produit, le contenu editorial, les séries télévisées, RTÜK, la publicité clandestine

\section{Özet}

Çalışma Türkiye'de ticari televizyon için önemi artan reklam uygulamalarından biri olan ürün yerleştirme ile yayıncılığın ticari-olmayan, kültürel boyutu arasındaki büyüyen gerilime ilişkin bir değerlendirme sunmaktadır. 'Ürün yerleştirme' kabaca, bir program akışı içinde bir ürünün veya markanın yer almasına veya bir ürüne veya markaya yapılan göndermelere dayalı bir reklam tekniğidir. Bu özelliğiyle aslında gizli reklam uygulamalarından ayrılması son derece zordur ve yakın zamana kadar birçok ülkede yayıncılığın 'reklam ve editöryal içerik arasındaki ayrım' ilkesine aykırı olduğu gerekçesiyle bir 'tabu' olarak kalmıştır. Ancak bu durum son yıllarda değişmiş ve pek çok ülkede 'ürün yerleştirmeyi' yasallaştıran düzenlemeler yapılmıştır. AB'deki değişikliklere paralel olarak, Türkiye'de de 2011 yılında yürürlüğe giren yeni bir yasa 16112 sayılı) ile ürün yerleştirme pratikte serbest bırakılmıştır. Mevzuattaki bu değişikliği takiben Türkiye'de medya endüstrisinde ürün yerleştirme artan oranda kullanılan bir reklam şekli ve kanallar için yeni bir gelir kaynağı haline gelmiştir. Çalışma kapsamında ürün yerleştirmeye ilişkin Avrupa Birliği $(A B)$ ve Türkiye mevzuatı eleştirel bir açıdan ele alınmış ve Türkiye'de medya sektöründe, özellikle de dizi sektöründe faaliyet gösteren profesyoneller ile yapılan görüşmelerle editöryal içerik ile ilgili kaygıları artıran somut gelişmeler anlaşılmaya çalışılmıştır. Çalışmada ürün yerleştirme uygulamalarının ' reklam ve editoryal içerik arasındaki ayrım' ilkesinin her zamankinden daha fazla zarar gördüğü bir piyasa ortamının ortaya çıkmasına neden olduğu ileri sürülmüştür.

anahtar kelimeler: ürün yerleştirme, editöryal içerik, televizyon dramaları, RTÜK, gizli reklam 


\section{Ürün Yerleştirme - Büyüyen Pazar ve Büyüyen Kaygılar}

Birkaç yıldır hem Avrupa'da hem de Türkiye'de televizyon izleyicileri yeni bir reklam türüyle karşı karşıya. Örneğin, İsveç'in en popüler bahçe işleri ile ilgili televizyon show'u Antligen Hemma'nın (TV 4) izleyicileri program sunucusuyla ünlü çimbiçme markalarından birinin satış mağazasını ziyaret ediyor ve bu marka altı dakika boyunca ekranda görülürken iki ürünün de tanıtımı yapılıyor. İsveç televizyon kanallarından TV4'te Prime- time'da ${ }^{1}$ altı dakika kendine yer bulan markanın, bunun sonucunda web sitesine yapılan ziyaretlerin \%180 arttığı gözleniyor (Morris 2011). Bu durum Avrupa Birliği'nin (AB) 28 ülkesinde ve yayıncılıkla ilgili kurallarını $A B$ ile uyumlulaştırmaya çalışan Türkiye'de reklam stratejilerinde yeni bir döneme işaret ediyor.

Türkiye'de de yarışma, eğlence, spor gibi farklı program türlerinde ve yerli dizilerde ürün yerleştirme uygulamaları artıyor. Örneğin, neredeyse tüm karakterleri reklam yıldızına dönüşen Yalan Dünya (Kanal D) dizisinin hemen hemen her bölümünde finans, gıda, ev eşyası gibi farklı sektörlerde hizmet veren markaların ürün yerleştirmeleri yapılıyor. Çocuklar Duymasın'da (Fox TV) masada birden Coca-cola ve promosyon ürünleri beliriyor. Kaynana Gelin Sedaya Gelin (Kanal D), Bir Fikrin mi Var (Sky Türk 360) gibi yarışma programlarında ürün yerleştirmesi yapılan ürünler katılımcılara hediye ediliyor, tanıtımı yapılıyor. Starcom/MediaVest Grubu Nar Ajans verilerinden hareket ederek 2011 HaziranAralık ayları arasında Türkiye'de televizyonda gerçekleşen ürün yerleştirme uygulamalarına dair şu veriler elde edilmiştir: 6 ayda yapılan ürün yerleştirme uygulaması sayısı toplam 1.349 'dur. Bu uygulamaların \% 31'i dizilerde, \%11'i kadın programlarında, \% 58'i diğer programlarda yapılmıştır. Ürün yerleştirme uygulamalarının yüzde 48'i pasif ürün yerleştirmedir ("En Çok", http://www. connectedvivaki.com). 2014 Ocak ayında ise en çok ürün yerleştirme yapılan ilk 10 program arasında ilk sırada 5212 saniye ile Kaynana Gelin Sedaya Gelin (Kanal D) adlı gündüz kuşağında yayınlanan yarışma programı yer alırken, listede Saba Tümerle Bu Gece (TV8), gibi farklı türden programların yanısıra üç dizi de yer almaktadır. ${ }^{2}$ 3P ajansı CEO'su Mehmet Akif Ebiçlioğlu'na göre dizilerin anlatısında farklı duyguların ön plana çıkması ve satın alma davranışında duyguların belirleyici olması, dizilerin ürün yerleştirme uygulamaları için en çok tercih edilen programlar arasında yer almasına neden olmaktadır (kişisel görüşme, 01.04.2014). Türkiye'de ürün yerleştirme uygulamalarına dair sayısal veriler, ağırlıklı olarak markaların ya da medya satın alma ajanslarının ölçümleme yapan kuruluşlara bildirimlerine dayanarak elde edilmektedir. ${ }^{3}$ Ancak Ebiçlioğlu'na göre kanal sayısının fazla

1 Ticari televizyon yayıncılığı için reklam fiyatları açısından en değerli zamanı kapsayan yayın saatleri.

2 Türkiye'de 2014 Ocak ayında gerçekleşen ürün yerleştirme uygulamalarına dair ayrıntılı bilgi için bkz: Ek 1

3 Türkiye'de televizyondaki ürün yerleştirme uygulamalarının takibi Interpress bünyesindeki Nar Ajans ve Nielsen Medya tarafından yapılmaktadır. Ürün yerleştirme uygulamalarının hangi kanalda, hangi programda, hangi zaman diliminde yapıldığı takip edilebilmektedir (Mehmet Akif Ebiçlioğlu, kişisel görüşme, 01.04.2014). 
olması ürün yerleştirme uygulamalarının hepsinin takip edilememesine neden olmaktadır. Dolayısıyla sayısal veriler çok 'net' değildir (kişisel görüşme, 01.04.2014). Tüm uygulamaların takip edilemediği düşünüldügünde pratikte ürün yerleştirme uygulamalarının sayısının çok daha yüksek olduğu söylenebilir. Türkiye'de toplam reklam harcamaları 2011 yılında 4 milyar 320 milyon TL, 2012 yılında ise 4 milyar 652 milyon TL.'dir ("Medya Yatırımları", www.rd.org.tr). 2012 yılında televizyonun reklam pastasındaki payı \% 56'dır ("Reklam pazarı", www. sabah.com.tr). 2012 yılında ürün yerleştirme uygulamalarının Türkiye'de reklam pastasındaki payının, barter'lar hariç TV reklam harcamalarının \% 1-2'si olduğu tahmin edilmektedir (Bir 2012) ${ }^{4}$. Ancak ürün yerleştirme yatıımlarının artma potansiyeline dikkat çekilmektedir.

Ürün yerleştirme, Oxford Medya ve Illetişim Sözlüğü'nde (2011) şöyle tanımlanır: Ürün yerleştirme "bir film veya televizyon ürününün içinde sahnenin bir parçası olarak bir ürünün veya markanın görünmesi yoluyla tanıtımının yapılmasıdır". AB'nin Görsel işitsel Medya Hizmetleri Yönergesi'nde ise ürün yerleştirmenin tanımı şu şekildedir: Ürün yerleştirme "bir ürün, hizmet veya ticari markanın, ücret veya benzeri bir karşılıkla, program içine dâhil edilerek veya bunlara atıf yapılarak program içinde gösterildiği her tür görsel işitsel ticari iletişimi ifade eder." ("Avrupa Birliği", http://www.rtuk.org.tr). Bir başka tanım ise, ürün yerleştirmenin "bir firmanın üretmiş olduğu ürün ya da hizmetleri, marka adını ya da herhangi bir pazarlama faaliyetini bir güzel sanatlar eseri içine olumlu bir imaj yaratmak üzere, profesyonel bir şekilde yerleştirmesidir" (Tığlı 2004: 23). Tanımlar çoğaltılabilir ancak, tüm tanımlar birbirlerine yakındır ve kabaca ürün yerleştirme ile kastedilen ticari değere sahip bir ürünün/hizmetin, tanıtım yapmak amacıyla görsel-işitsel metnin (film, televizyon programları) içine yerleştirilmesidir. Bu açıdan, ürün yerleştirme yeni bir reklam tekniği olarak geleneksel spot reklamlara alternatif olarak görülmektedir.

Ürün yerleştirmenin reklamveren açısından başlıca avantajları arasında tüketiciye ürünün gündelik yaşamda nasıl kullanıldığının gösterilmesi, gerçeklik duygusu yaratması, ünlü ve popüler oyuncuların markayı kullanarak markaya prestij kazandırması, reklamveren firmanın ürün satışlarını artıırması, reklama göre 'daha az agresif ve daha yumuşak' bir tutundurma faaliyeti olması, ürünün yerleştirdiği programın değişik ülkelerde değişik kanallarda değişik zamanlarda tekrar tekrar gösterilme olanağı sayılmaktadır (Tığlı 2004: 35-37). Ürün yerleştirme uygulamaları temel olarak üç farklı şekilde yapılmaktadır: Görsel (visual), sesli (spoken) ve kullanım (usage) (Wasko, 2003:155). ${ }^{5}$ Ancak sektörde ürün yerleştirme uygulamalarına dair farklı sınıflandırmalar yapılmaktadır.

4 Ebiçlioğluna'na göre ise ürün yerleştirmenin TV reklam pastasındaki payı \% 0.5 civarındadır ( Kişisel görüşme, 01.04.2014). 2013 yılında televizyon reklam gelirleri toplamı içine ürün yerleştirme, tele alış veriş ve diğer gelirler eklenmiştir. Bu kalemlerin gelirler toplamı içindeki oranı \%1.73 düzeyindedir (Bkz: Çelikcan, 2014:5).

5 Ürün yerleştirme uygulamalarına dair literatürde yaygın olarak kullanılan farklı bir sınıflandırma ise görsel (visual), sözel (audio), hem sözel hem de görsel (audiovisual)yerleştirme stratejileridir (Argan vd., 2007: 161). 
Starcom/MediaVest Grubu 2011 Haziran-Aralık aylarında Türkiye'de televizyonda gerçekleştirilen ürün yerleştirme uygulamalarını beş kategoriye ayırır: ("En Çok", http://connectedvivaki.com).

Senaryo Entegrasyonu: Ürün ya da hizmetin, senaryo akışı içerisinde hem aktif biçimde kullanıldığı hem de ürün veya hizmete dair slogan veya yaşam cümleciklerinin dile getirildiği uygulamalar

Aktif Ürün Yerleştirme: Ürün ya da hizmetin, sahneler içerisinde aktif bir biçimde kullanıldığı uygulamalar

Ürün Tanıtımı ve Hediye: Özellikle yarışmalarda, ürün ya da hizmetin katılımcılara hediye edildiği ve/veya tanıtımının yapıldığı uygulamalar

Sesli Ürün Yerleştirme: Ürün ya da hizmetin sahne içerisinde gösterilmediği, sadece ürüne ya da hizmete dair sözlü ifadenin yer aldığı uygulamalar

Pasif Ürün Yerleştirme: Ürünün sahne içerisinde gösterildiği ama kullanılmadığı uygulamalar

Nielsen Medya ise 2014 Ocak ayı itibariyle Türkiye'de televizyondaki ürün yerleştirme uygulamalarını Hediye-Ürün Tanıtım, Pasif, Aktif, Dijital, Senaryo Entegrasyon ve Sesli Ürün Yerleştirme olarak altı kategoriye ayırır. Maliyet açısından değerlendirildiğinde ise ürün yerleştirme spot reklamlara alternatif bir yöntemdir. 6 Ancak daha şimdiden Türkiye'de fiyatların çok yüksek rakamlara ulaştığı söylenebilir. Fiyatlar kanallara ve yapımlara göre değişse de ürün yerleştirmenin maliyeti 50.000 ila 300 bin TL arasındadır. Farklı ürün yerleştirme uygulamalarının fiyatlandırması en yüksekten en düşüğe doğru şu şekildedir: Senaryo entegrasyon, aktif entegrasyon, pasif entegrasyon ve dijtal entegrasyon (Mehmet Akif Ebiçlioğlu, kişisel görüşme, 01.04. 2014). Nitekim Medya planlamacı İlyas Demir'e göre Türkiye'de ürün yerleştirmenin maliyetinin yüksek olması, ilk başlarda bazı reklamverenlerin ürün yerleştirme uygulamalarına mesafeli durmasına neden olmuştur. Bazı şirketler neredeyse bir haftalık reklam bütçelerini ürünlerinin bir dizinin/programın birkaç saniyesinde görülmesi için harcamayı riskli bulmuştur (kişisel görüşme, 06.07.2012.) Türkiye'de özellikle prime-time'da yayınlanan reytingi yüksek bir dizide ürün yerleştirme uygulamasının maliyeti iddialı Hollywood yapımlarındaki uygulamalardan yüksek olabilmektedir. Bunun nedeni olarak ürün yerleştirmeyi yeni bir gelir kaynağı olarak gören televizyon kanallarının fiyatlandırma politikaları gösterilmektedir (Mehmet Akif Ebiçlioğlu, kişisel görüşme, 01.04. 2014).

Ticari kazanç için olumlu bir gelişme olarak nitelendirilebilecek bu durum, yayıncılık etik ve ilkelerine dair tartışmaları da beraberinde getirmektedir. Ürün

6 Örneğin Almanya'da ürün yerleştirme uygulamaları 70.250 başlayıp $422.000 \$$ ve üstüne çıkmaktadır. İspanya'da ürünün yaklaşık altı saniye ekranda göründügü pasif ürün yerleştirmenin fiyatı 5600-8400 \$ iken, aktörün ürüne dokunduğu yada kullandığı ortalama üç saniyelik bir aktif ürün yerleştirmenin fiyatı 11.250- 14.000 \$'dır. Daha sofistike yerleştirmelerin fiyatı 28.000 $280.000 \$$ arasında değişmektedir (Morris, 2011). 
yerleştirme uygulamalarının kabul edilebilir olup olmadığına dair tartışmalar temel olarak iki ana başlık altında toplanmaktadır: Genel etik kaygılar ve belli ürünlerin (sigara, silah, alkol vb.) yerleştirilmesinin yapılmasına dair kaygılar (Gould v.d. 2000 ). Genel etik kaygılar editöryal içeriğe (örn. filmlere) yapılacak her türlü ürün yerleştirmenin aldatıcı ve biliçaltı (subliminal) bir nitelik taşıyabileceği endişesine gönderme yapar. Belli ürünlere yönelik (örn. sigara) kaygllar ise üzerinde görüş birliğine varılan sağlığa zararlı olabilecek ürünlerle ilgili reklam yasağının ürün yerleştirme ile delinmesine ilişkin endişelere gönderme yapar. Aslında, izleyicilerin editöryal içerikle ticari mesajları birbirinden ayırt edememe olasılığı, ürün yerleştirmeye dair tüm tartışmaların merkezindedir. Ürün yerleştirmenin kaynağın, iletişimin amacının ve hatta mesajının açıkça ortaya koyulmadığı bir iletişim şeklini esas aldığı görüşü ürün yerleştirmenin 'aldatıcı' bir reklam tekniği olarak nitelendirilmesine neden olmaktadır (Hackley v.d. 2008: 116-117). Ürün yerleştirmeye dair tartışmalar izleyicilerin ne zaman ve kim tarafından etkilendiklerinden haberdar olma hakkının olup olmadığı sorusunu gündeme getirmektedir (Ginosar 2012: 97). Öte yandan, 'tüketicinin egemenliği' tezini savunan kesimler günümüzde tüketicilerin farklı pazarlama tekniklerinden haberdar olduğunu görüşünden hareket ederek, ürün yerleştirme uygulamalarını desteklemektedirler (Hackley v.d. 2008: 116-117).

\section{Ürün Yerleştirmenin Tarihi Gelişimi}

Bu tartışma içinde daha sağlam bir duruş geliştirmek için 'ürün yerleştirme' uygulamalarının tarihsel gelişimine bakmak gerekir. Ürün yerleştirme aslen sinema tarihinin başlangıcından beri varolan bir uygulama olmakla birlikte uygulama, sinema dünyasında 1980 'lerde ve takip eden dönemde de televizyonda yaygınlaşır. Jay Newell, Charles T. Salmon \& Susan Chang'e göre ürün yerleştirmenin ilk örnekleri Lumiere Kardeşler'in filmlerinde görülmeye başlanır (2006: 579580). Ancak, Amerika'da 1991 yllında kurulan The Entertainment Resources \& Marketing Association (ERMA) adlı meslek birliğinin yöneticilerinden birinin belirttiği üzere endüstrinin tüketicilerin ürün yerleştirme uygulamalarına karşı olduğuna dair öngörü ve gözlemleri, uzun süre Hollywood'un ürün yerleştirme uygulamalarına mesafeli bakmasına neden olur (akt. Wasko 2003: 161). 1960'larda ve 1970 'lerde stüdyoların etkisinin azalması, bağımsız yapımcıların ortaya çıkması, yerinde çekimlerin artması gibi farklı faktörler ürün yerleştirme uygulamalarııın artmasında rol oynar (Balasubramanian v.d. 2006: 116). Ürün yerleştirme 1980 öncesinde de Hollywood sinemasında başvurulan bir reklam yöntemi olsa da (Balasubramanian 1994; Miller 2004) ${ }^{7}$, ürün yerleştirme uygulamalarının profesyonelleşmesi, endüstriyel bir boyut kazanması 1980'li yıllarda gerçekleşir

7 Newell v.d. (2006) daha önceki dönemde yapılan çalışmaları da referans vererek, ürün yerleştirme öncesi kullanılan film reklamclığına dair exploitation, plugs, co-operative advertising, tie-in advertising ve tie-ups gibi kavramların daha 1920 'lerde kullanılmaya başlandığını belirtirler. Bu kavramların içeriklerini tek tek incelemek buradaki amacımızın dışında olmakla birlikte hepsinin belli bir ürünün ekranda (on-screen) veya basınla ilişkiler kanalıyla tanıtılması ve özendirilmesini kapsadığı söylenebilir. 
(Wasko 2003: 155). Ancak ürün yerleştirme uygulamaları, Thomas Schatz'ın "Yeni Hollywood" olarak nitelendirdiği bu dönemde, büyük bütçeli, her kesimden izleyiciye hitap etmeyi hedefleyen, görsel efektleri ve mitolojik özellikler taşıyan hikâyeleriyle dikkat çeken blockbusterlarla özdeşleşir. Hollywood stüdyolarının medya ve iletişim alanında faaliyet gösteren büyük şirketlerin bünyesine girmeye başladığı bu dönemde, Hollywood sadece gişe gelirleriyle yetinmeyerek, filmlere dair pazarlanabilir olan her şeyi pazarlamaya başlar. Eğlence sektörünün farklı alanlarında yatıımları bulunan küresel medya şirketleri, şirketleri arasındaki sinerjiden faydalanarak, karlarını attırmayı hedefler (Tüzün 2013: 86-89). 1982 tarihli E.T. (Steven Spielberg 1982) ürün yerleştirme açısından bir dönüm noktası olarak kabul edilir. Filmde Hershey'nin Reese's Pieces ürün yerleştirmesinin yer almasının ardından Reese's Pieces satışları yüzde 65 artar (Buss 1998).

Türkiye'de ise 1990'da radyo televizyonda kamu tekelinin son bulmasının ardından ticari televizyon kanallarında ürün yerleştirme uygulamaları görülmeye başlanır. 2011 yılına kadar radyo ve televizyonda ürün yerleştirme kâğıt üzerinde yasak olsa da fiili durum farklıdır. Örneğin 1996'da Mustafa Sandal'ın Araba adlı klibinde alkollü bir ürünün yerleştirmesinin yapılması kamuoyunda gizli reklam konusundaki tartışmaları tetikler. 2000'li yıllarda Türkiye'de sinema filmlerinde de ürün yerleştirme uygulamalarının sayısı artar. Merih Taşkaya (2009) 1987, 1997, 2007 yıllarında en çok izlenen 30 sinema filmini içerik analizi yöntemiyle inceleyerek, 2000'li yıllarda ürün yerleştirme uygulamalarında film, sahne, süre ve ürün sayısı bazındaki artışı sayısal verilerle ortaya koymaktadır. 12 farklı markanın görsel ve sözel yerleştirmesi yapılan G.O.R.A. (Ömer Faruk Sorak, 2004) Türk sinemasında ürün yerleştirme açısından bir dönüm noktası olarak kabul edilebilir (Pekman ve Tüzün 2008: 343). Filmde görsel, sözel, hem görsel hem sözel gibi çeşitli ürün yerleştirme stratejileri kullanılmış, Avea, Yedigün gibi farklı sektörlerde faaliyet gösteren firmaların ürün/hizmetlerinin yerleştirmesinin yanısıra dikkat çekecek yoğunlukta sigara ve alkol ürününün yerleştirmesi yapılmıştır (Argan v.d. 2007).

ABD'de radyo ve televizyonda ürün yerleştirme uygulamalarının yaygınlaşmasını geciktiren temel faktörlerden biri ticari reklamlar için ayrılan sürenin kısıtlı olması ve ürün yerleştirme uygulamalarının düzenleyici örgütler tarafından program içi reklam olarak değerlendirilerek, yayıncılara verilen toplam reklam süresinden düşülmesi intimalidir. Ayrıca ürün yerleştirme uygulamaları karşılığında Hollywood stüdyolarına sunulan tanıtım ve bedava dekor, kostüm vb. olanaklar, o dönemde rekabetin sinemaya göre daha sınırlı olduğu ve yapım giderlerinin düşük olduğu televizyon ve radyo için o kadar cazip değildir. Bu konuda kamu otoritelerinin görüşü de tamamen olumsuzdur. Yayıncılık Reklam Bürosu (Broadcast Advertising Bureau) yayıncı şebekelerden ürün yerleştirme uygulamalarını engellemelerini istemiştir (Newell v.d. 2006: 585). Ancak Newell ve diğerlerinin (2006) 'masa altı ayarlamaları' (under table arrangements) diye adlandırdıkları yöntemlerle, yayıncılar ve reklamcılar arasında anlaşmalar yapılarak ürün yerleştirme uygulamaları gerçekleşir. 
Yukarıdaki paragraflarda da belirtildiği üzere ürün yerleştirme dünyanın dört bir yanında serbest pazar söyleminin yükselişe geçtiği, tüketimin gündelik yaşam üzerindeki belirleyiciliğinin arttığı 1980'li yıllarda yaygın bir uygulamaya dönüşür. Nitekim neo-liberal politikalar doğrultusunda, yayıncılıkta piyasanın serbestçe çalışmasını engel olduğu ileri sürülen mevzuatın esnekleştirilmesini öngören deregülasyon sürecinin ivme kazanması (Pekman 1997), reklamlara dair mevzuatların da esnekleştirilmesine neden olur. Avshalom Ginosar (2012: 97) ürün yerleştirmeyi 1980 'ler ve sonrasında düzenli bir uygulama haline getiren teknolojik gelişmelere bağlı değişimleri ise dört başlık altında toplar: Birincisi, 'sayısal devrim' diye adlandıılan teknolojik altyapıdaki değişimlerin izleyicilerin çok sayıda kanala erişimini olanaklı kılmasıdır. Bu durum kanal sayısındaki artışa paralel olarak izleyici gruplarının parçalanmasına neden olarak, tüm izleyicilerin aynı reklamlarla hedeflendiği geleneksel reklam uygulamalarının etkisini azaltmıştır. İkincisi, teknolojik gelişmeler ve kişisel video kaydedicilerin kullanımının yaygınlaşmasıyla, izleyicilerin spot reklamları etkisiz kılacak izleme pratikleri edinmesidir. Üçüncüsü, internetin reklam açısından yeni ve dinamik bir mecra olarak ticari yayıncııkta rekabetin doğasını büyük ölçüde etkilemesidir. Dördüncü ve sonuncusu, ürün yerleştirmenin bu yeni rekabet ortamında ticari yayıncılar için hem alternatif bir reklam yolu hem de reklamdan izleyicinin kaçmasını engelleyen etkin bir reklam tekniği olarak öne çıkmasıdır8.

Altı çizilen gelişmelere paralel olarak son yıllarda küresel ürün yerleştirme yatırımları artar. 2011 yılında küresel ürün yerleştirme harcamaları bir önceki yıla göre $9.8 \%$ artarak 7.39 milyar dolara ulaşır. \% 57,6 pazar payı ile ürün yerleştirme pazarının lideri konumundaki Amerika'da, ürün yerleştirme harcamaları 4.26 milyar dolara ulaşır. En çok ürün yerleştirme uygulaması televizyon ve sinema mecralarında gerçekleşir. Küresel TV ürün yerleştirme harcamaları ise $A B$ ülkelerinde ve Asya ülkelerinde reklam mevzuatlarındaki değişikliklerin de etkisiyle 2011'de 10,9\% artarak 4.76 milyar dolara ulaşırken, Amerika'da \%11 artarak 2011 yılında 2.83 milyar dolara ulaşır ("Global Product", www.pqmedia. com).

Zaman içinde ürün yerleştirmenin önemli bir gelir kaynağı haline gelmesi ve yukarıda belirtilen diğer nedenlerden dolayı, piyasa güçlerinin baskısıyla, ürün yerleştirme kamu otoritelerinin yeni medya siyasaları oluşturma süreçlerinde gündem başlıklarından biri haline gelir. Türkiye'de özellikle ekonomi ve ticaretten sorumlu bakanlıklar ve kamu otoriteleri ürün yerleştirme uygulamalarının yasallaşmasını ve yaygınlaşmasını destekler. Hükümetin ürün yerleştirme uygulamalarına destek vermesinde, Türk dizilerinin dış pazarlarda gördüğü talep ve hükümetin dizi ve filmleri 'Türk malı imajının' tanıtılması ve

8 RTÜK'ün Televizyon İzleme Eğilimleri Araştırması'na göre Türkiye'de izleyicilerin yüzde 56.4'ü reklamları gördüğü anda kanal değiştirirken, \% 38'i reklamların bir kısmını izleyip kanal değiştirmekte, sadece \%10.7'si ise reklamların tamamını seyretmektedir ("Televizyon İzleme", www.rtuk.org.tr). Araştırma Türkiye'de de izleyicilere spot reklamları izlettirmenin güç olduğunu ortaya koyar. 
pazarlanmasında kullanma hedefi önemli rol oynar. 2010 Nisan ayında ürün yerleştirme uygulamalarının yasallaşmasından 1 yı önce, Dış Ticatten Sorumlu Devlet Bakanı Zafer Çağlayan dizi ve filmlerin ihracat ürünü sayılması için bir düzenleme yaptıklarını, televizyon programlarında yasaklar nedeniyle markaların 'buzlanmaması' için reklam, sponsorluk ve ürün yerleştirmenin 'ticari iletişim' tanımı altında toplanacağını belirtir (Kara 2010). Dönemin Dış Ticaretten Sorumlu Devlet Bakanı'nın demeçleri ürün yerleştirme uygulamalarının yasallaşması konusunda hükümetin tavrını ortaya koyar. Nitekim 2012 yılında Döviz Kazandırıcı Hizmet Ticaretinin Desteklenmesi Hakkında Tebliğ 25 Haziran 2012'de Resmi Gazete'de yayınlanarak yürürlüğe girer. Bu tebliğ ile dizi ve film sektörüne yurtdışı tanıtım ve pazarlama destekleri verilmesi öngörülmektedir. Dizi ve film sektörü döviz kazandırıcı hizmetler olarak nitelendirilmektedir ("Döviz Kazandırıcı", www.resmigazete.gov.tr). Sinema Eseri Yapımcıları Meslek Birliği (SEYAP)'ın film ve dizilerde ürün yerleştirmenin serbest kalması gerektiğine dair bildirisi ise endüstrinin ürün yerleştirme uygulamalarına dair görüşlerini ana hatlarıyla ortaya koyar: Bildiride ürün yerleştirmenin endüstri için önemli bir gelir kaynağı haline geleceği ve Türk sinemasının rekabet gücünü arttıracağı belirtilmektedir. Türk ürün ve markalarının yurt dışında tanıtımına katkıda bulunma potansiyeline dikkat çekilmektedir ("SEYAP Film”, www.kilimfilim.com). Türkiye'de ürün yerleştirme pazarının büyüme potansiyeli Amerika'daki ERMA'ya benzer istanbul merkezli Branded Entertainment Europe Mena Asia Association (BEEMAA) adlı bir meslek birliğinin 2014 Mart ayında kurulmasına neden olur.

\section{Yasal Düzenleme Sürecinde Ürün Yerleştirmenin Meşrulaştırılması}

Türkiye'de ürün yerleştirmeye ilişkin siyasa değişiklikleri doğrudan doğruya $A B$ 'deki yeni medya siyasaları ile bağlantılıdır. Bu nedenle önce 'AB'deki medya politikasındaki dönüşümü kısaca da olsa ele almak gerekir. AB'de üye ülkeler arasında geçerli ortak yayıncılık siyasaları açısından 1984 yılı bir dönüm noktasıdır. Avrupa Komisyonu tarafından bu tarihte hazırlanan bir Yeşil Dokümanda tüm üye ülkelerde reklama dayalı bir yayıncılık anlayışının önünü açacak bir siyasa geliştirilmesi önerilmekte idi. O tarihlerde AB (ya da o dönemki ismiyle Avrupa Topluluğu) ülkelerinde reklam uygulamaları oldukça sınırlıydı (Pekman 1997) ve Yeşil Doküman'da reklam sürelerindeki kısıtlamaların ticari gelişmeyi engellediği ileri sürülmekteydi. Reklamcılığa ilişkin bu serbestleşme Yeşil Doküman'ın doğrudan bir sonucu olarak da görülebilecek, 1989 yılında yürürlüğe giren Avrupa Sınır Ötesi Televizyon Yönergesi (ASÖT) ile somut bir siyasaya dönüştü.1994 yılında Türkiye'de de kabul edilen bu yönergenin özellikle reklamla ilgili hükümleri yönergenin yürürlüğe sokulduğu ülkelerin ticari yayıncılığında belirleyici oldu.

Reklamcılığa dayalı yayıncılık ile ilgili altı çizilen bu serbestleşme süreci özellikle 1990'ların ikinci yarısında hız kazanmıştır. Philip Schlesinger'e göre 1994 GATT (Ticaret ve Tarifeler Genel Anlaşması) sonrası dönemde AB ekonomi merkezli politikadan daha teknik ve ekonomi odaklı politikaya kaymıştır. Bu yeni zamanlarda artık 'Avrupa görsel-işitsel uzamı' yerine daha çok 'Avrupa 
bilgiçağı' ifadesi kullanılır olmuştur (akt. Gencel-Bek 2003: 27). Nitekim 1997 yılında revize edilen ASÖT Yönergesi özellikle reklamla ilgili uygulamalarda yeni bir serbestleşmeye yol açar. Telealışveriş gibi kavram ve düzenlemeler yönergeye eklenir. Tüm bu siyasa sürecinde reklamclıkla ilgili 'kültürel-içeriğe ilişkin' kaygıların telafi edilebilmesi için yönerge metninde de içerik ile reklamın ayrıması, reklamların program aralarına alınması gerekliliği net bir şekilde ifade edilir. Bunlar dışında yayın içine alınacak ve ticari amaç güden reklamlar ise gizli (surreptitious) reklam olarak nitelendirilerek, tümüyle yasaklanır. Bu bir yandan tüketici olarak izleyicinin korunması, bir yandan da Avrupa'da kültürel korunma ve çeşitlilik hedef ve ilkeleriyle ilgili bir durumdur. Bu bağlamda Cem Pekman Avrupa Konseyi'nin çıkış noktasındaki televizyonun özelleşmesi-ticarileşmesi karşısında ulusal kültürlerin ve kamu yayıncılığının korunması amacıyla, AB'nin özelleşme yanlısı tavrı arasındaki çatışmaya dikkat çeker (2001: 221). Nitekim ticarileşen bir yayıncılık modeli daha başından itibaren siyasa sürecine eleştirel yaklaşanlar tarafından televizyonun 'Amerikanlaşması' olarak değerlendirilir. ABD finans ağlarının yanısıra eğlence kültürü ürünlerinin de Avrupa pazarlarına akın etmesi, özellikle aydın çevrelerinde Avrupa'nın yüksek kültür geleneğine bir saldırı olarak değerlendirilir (Mattelart 2001: 61).

2002 yılında başlayan yeni siyasa süreci içinde ise bir 'tabu' olarak o zaman kadar gelen reklamın içerikten uzak tutulup ancak program aralarına alınması uygulaması (bant reklamlar hariç) yeni geliştirilen söylemsel gerekçelendirilmeler ile aşılmaya çalışıır. Süreç içinde pekçok bağımsız rapor, Komisyon İletişim Belgesi (Commission Communication) ${ }^{9}$ vb. siyasa metni üretilmiş, uzman ve odak gruplar toplanmış, konferans ve toplantılar düzenlenmiş ve de 200 'den fazla katılımcının pozisyon metinleri (position paper) gönderdiği iki safha halinde bir kamu istişaresi düzenlenmiştir. Uzun süren, geniş katılımlı bir siyasa süreci ya da daha popüler bir deyimle 'yönetişim' süreci sonucunda yeni yönerge, Görsel İşitsel Medya Hizmetleri Yönergesi (GiMHD) hazırlanır.

Bütün siyasa süreci boyunca en tartışmalı konuların başında 'ürün yerleştirme' gelir. Tartışma sürecinde medya alanında faaliyet gösteren endüstri temsilcisi konumundaki ticari şirketler ile tüketici ve emek örgütleri ve kamu hizmeti yayıncılarının çoğunluğunu oluşturduğu gruplar iki ana kampı oluşturur. Illk kamp ürün yerleştirmeye hem geleneksel hem de yeni medya izin verilmesini savunurken, ikinci kampa üye örgütler ürün yerleştirmenin ya tamamen yasak kalmasını ya da ürün yerleştirmeye sıkı kurallar çerçevesinde kısıtı biçimde izin verilmesini savunmuşlardır. Yeni yönerge metnini hazırlayan Avrupa Komisyonu ise bu görüş ayrılığında birinci gruba yakın bir tutum sergiler (Taşdemir 2014). Komisyonun tavrı özellikle 'ürün yerleştirmeye' izin verilmesinin zeminini

9 Komisyon İletişim Belgesi (Commission Communication) Avrupa Komisyonu tarafından hazırlanan ve zorunlu olarak uygulanması gerekmeyen görüşleri içeren bir siyasa dokümanıdır. Komisyon her hangi bir konu ile ilgili kendi görüşlerini duyurmak istediği zaman bir İletişim Belgesi (Comminication) yayınlayabilir. Kavramın resmi tanımı için bkz. http://ec.europa.eu/civiljustice/ glossary/glossary_en.htm\#Communication (son ziyaret tarihi 08.10.2014) 
hazırlayan Komisyonun yayınladığı 2004 tarihli 'yorumlamalı iletişim belgesi'nde (interpretive communication) netleşir ${ }^{10}$. Bu metinde ürün yerleştirmeye izin verilmesi ilk defa şöyle gerekçelendirilir: Yeni reklam tekniklerinin “izleyicilerin reklamı yanlış anlamalarını engellemek için akustik ve optik yollarla program içeriğinden ayrı tutulması ve kolay bir şekilde tanınmaları" şartıyla ürün yerleştirme, "içerik ve reklam arasındaki ayrıma ilişkin temel ilke" ile çelişmez ("Commission Interpretative", www.euromedaudiovisuel.net). Siyasa sürecinin bu metinden sonraki safhalarında, Komisyonun ortaya koyduğu bu "çözüm" yolu özellikle büyük medya şirketleri tarafından desteklenir. Avrupa Parlamentosu ve Konseyin onay sürecinden sonra da ürün yerleştirmeye bu şartlarla izin veren bir yönerge metni yasalaşmış olur. Ürün yerleştirmeye ilişkin Görsel İşitsel Medya Hizmetleri Yönergesi'nde (2010) en önemli paragraf ve maddeler şunlardır ${ }^{11}$ :

\section{Paragraflar (Recital)}

(81)Ticari ve teknolojik gelişmeler, kullanıcılara görsel-işitsel medya hizmetlerini kullanmalarında artan seçenek ve sorumluluk vermektedir. Genel çıkarların amaçlarıyla orantılı kalabilmek için, düzenleme televizyon yayınlarıyla ilgili belirli bir düzeyde esnekliğe izin vermelidir. Ayrım ilkesi televizyon reklâmı ve tele-alışveriş ile sınılı tutulmalı, Üye bir Devlet aksine karar almadıkça, ürün yerleştirmeye belirli hallerde izin verilmelidir. Ancak ürün yerleştirme, gizli yapılması halinde, yasaklanmalıdır. Ayrım ilkesi, yeni reklâm tekniklerinin kullanımını engellememelidir.

(90)Gizli görsel-işitsel ticari iletişim, tüketiciler üzerindeki olumsuz etkisi nedeniyle bu Yönerge tarafından yasaklanan bir uygulamadır. Gizli görsel-işitsel ticari iletişim yasağı, izleyicinin ürün yerleştirmenin varlığı hakkında uygun bir şekilde bilgilendirildiği bu Yönerge çerçevesinde, yasal ürün yerleştirmeyi kapsamamalıdır. Bu bilgilendirme belirli bir programda ürün yerleştirmenin yapıldığını işaret etmek suretiyle, örneğin tarafsız bir logo aracılıyla, yapılabilir.

(93)Bunun da ötesinde, program destekleme ve ürün yerleştirme, medya hizmet sağlayıcısının editöryal bağımsızlığını ve sorumluluğunu etkileyecek şekilde program içeriğini etkilemesi halinde yasaklanmalıdır. Bu durum tematik yerleştirmelere ilişkindir.

\section{Madde 11.}

2. Ürün yerleştirme yasaklanacaktır.

3. Ürün yerleştirme içeren programlar, aşağıda yer alan koşulların hepsini içerecektir:

(a)Bunların içeriği ve televizyon yayınları olması halinde yayın akışı, hiçbir koşul altında medya hizmet sağlayıcısının sorumluluğuna ve editöryal bağımsızığına etki edecek şekilde etkilenmeyecektir,

(b)Ürün veya hizmetlerin, özellikle bu ürünlere veya hizmetlere özel tanıtıcı atıflar yaparak, satın alınmasını veya kiralanmasını doğrudan teşvik etmeyecektir,

10 Tam adı "Commission interpretative communication on certain aspects of the provisions on televised advertising in the "Television without frontiers" Directive" (2004/C 102/02).

11 Alıntılar için bkz. Avrupa Birliği Görsel İşitsel Medya Hizmetleri Yönergesi (http://www.rtuk.org. $\operatorname{tr} / \#$, son ziyaret 09.10.2013) 
(c)Söz konusu ürüne aşırı önem vermeyecektir,

(d) İleyiciler ürün yerleştirmenin varlığı hakkında açıkça bilgilendirilecektir. İleyici açısından herhangi bir karışıklığı önlemek amacıyla, ürün yerleştirmesi içeren programlar, programın başında ve sonunda ve reklam arası sonrasında program başladığında uygun bir şekilde tanınır kılınacaktır.

Sonuçta, madde 11 'in 2. fıkrasında ürün yerleştirmenin yasaklanacağı belirtilirken, 3. fıkrada ürün yerleştirmenin hangi koşullar altında serbest bırakılacağı açıklanır. Bu şekilde ürün yerleştirmeye kağıt üzerinde ilkesel olarak izin verilmese de 'yorumlamalı iletişim belgesi'nde yer alan ifadelere benzer ifadelerle, ürün yerleştirme yasal bir çerçeveye kavuşturulur. Ürün yerleştirmenin pratikte serbest bırakılmasının bir diğer telafisi olarak da üye devletlerin haberlerde, çocuklara yönelik programlarda ve dini içerikli programlarda ürün yerleştirmeyi yasaklamasının önü açıır. Ayrıca ülkelerin kültürel farklarına ve hassasiyetlerine göre ürün yerleştirme uygulamalarına dair sınırlandırmalarında bazı farklııılar görülmektedir. Örneğin obezite konusunda sorun yaşanan İngiltere'de yağlı, tuzlu ve şekerli yiyeceklerin yerleştirmesinin yapılması yasaktır (O'Reilly 2011). Ayrıca diğer televizyon reklamları gibi ürün yerleştirme uygulamalarında da alkol, tütün mamulleri ve ilaçlarla ilgili kısıtlayıcı hükümler ya da yasaklar vardır.

GiMHD'nin üye devletlerde uygulamaya geçirilmesi için bir son tarih vermesinin ardından ${ }^{12}$ Türkiye'de de yeni yayıncılık yasası için kritik adımlar atılmıştır. Bu tarihe kadar yeni yayıncılık yasası için ilgili üst kurullar, özellikle Radyo ve Televizyon Üst Kurulu (RTÜK) nezdinde çalışmalar yoğunlaşmış ve yeni yasa taslağı yıl içinde Başbakanlık'tan Türkiye Büyük Millet Meclisi'ne (TBMM) gönderilmiştir. Yeni yasa ile ilgili parlemento süreci ise 15 Şubat 2011 tarihinde tamamlanmış ve 6112 sayılı Radyo ve Televizyonların Kuruluş ve Yayın Hizmetleri Hakkında Kanun 3 Mart 2011 tarihinde Resmi Gazete'de yayımlanarak yürürlüğe girmiştir. Kanunun 13. Maddesiyle ürün yerleştirme düzenlenir. Özellikle ticari yayıncılık açısından yeni bir serbestleşme anlamına gelen GiMHD'deki 'ticari iletişim' ile ilgili hususlar yerel mevzuata da alınmıştır. Bu şekilde ürün yerleştirme Türkiye'de yasal bir çerçeveye kavuşmuş düzenlemeler arasına girmiştir. İlgili yasa maddelerinin uygulanmasına yönelik RTÜK, bir de yönetmelik hazırlayıp, yayınlamıştır. RTÜK'ün yasayla aynı yıl yürürlüğe giren Yayın Hizmeti ve Usul ve Esasları Hakkında Yönetmeliğı'nde, ilgili maddeler şu şekildedir: ("Yayın Hizmeti", www.rtuk.org.tr)

g) Gizli ticarî iletişim: Medya hizmet sağlayıcı tarafından reklam yapmak maksadıyla veya kamuyu yönlendirebilecek şekilde; mal veya hizmet üreticisinin faaliyetinin, ticarî markasının, adının, hizmetinin ve ürününün reklam kuşakları dışında ve reklam yapıldığına ilişkin açıklayıcı bir ses veya görüntü bulunmaksızın programlarda sözcükler veya resimler ile tanıtımasını

12 Bu süre önce 2009 ve ardından 2010 olarak belirlenmişse de, daha sonra $A B$ otorilerince yönergenin ulusal mevzuatlara geçirilmesi için son tarih olarak 2012 yılı belirlenmiştir (Taşdemir, 2014). 
z) Ticarî iletişim: Radyo ve televizyon reklamları, program desteklemesi, telealışveriş ve ürün yerleştirmeyi de kapsamak üzere, ekonomik bir faaliyette bulunan gerçek veya tüzel kişinin, ürün, hizmet veya imajını, doğrudan veya dolaylı olarak tanıtmak amacıyla tasarlanmış sesli veya sessiz görüntülerin bir ücret veya benzeri bir karşılıkla ya da öz tanıtım amacıyla bir programla birlikte ya da bir program içine yerleştirilerek verilmesi

\section{Yayın Hizmetlerinde Ticari İletişime İlişkin Genel Esaslar bölümü Madde} 9'da şu bentler yer alır:

(1) Ticarî iletişim, yayın hizmetinin diğer unsurlarından görsel ve/veya işitsel

olarak kolayca ayırt edilebilir olmak zorundadır.

(2) Ticarî iletişimde bilinçaltı teknikleri kullanılamaz.

(3) Gizli ticari iletişime izin verilemez.

(4) Haber bülteni ve haber programlarını düzenli olarak sunan kişilerin görüntü veya seslerine ticarî iletişimlerde yer verilemez.

(5) Ticarî iletişim, medya hizmet sağlayıcının editöryal bağımsızlığını ve program içeriğini etkileyecek şekilde kullanılamaz.

Yasadaki temel ilkelere uygun olarak ürün yerleştirmeye ilişkin yönetmelikte de benzer ifadeler yer almıştır. Ürün yerleştirmeye özel olarak getirilen yönetmelik maddesi ise şöyledir:

MADDE 14 - (1) Sinema ve televizyon için yapılmış filmler, diziler ile spor ve genel eğlence programlarında ürün yerleştirme yapılabilir. Ürün yerleştirme uygulamaları ticarî iletişimle ilgili düzenlemelere tabidir.

(2) Ürün yerleştirme ile ilgili bilgilendirmede, ürün yerleştirme uygulaması yapılacak programın başında, sonunda ve her reklam kuşağı sonrasında program başladığında, "Arial" yazı tipinde, "Normal" yazı stili ve boyutu 15 piksel büyüklügündeki "Bu programda ürün yerleştirme bulunmaktadır." Ifadesi yayınlanır. Söz konusu bilgilendirme yazısının ekranda akan yazı ile belirtilmesi durumunda izleyicilerin okuyabileceği bir hızda olması; ekranda sabit bir yazıyla belirtilmesi durumunda ise ekranda en az 10 saniye kalması sağlanır.

(3) Genel olarak, ürün yerleştirme, programın bütünlüğünü bozmamalıdır. Ürün yerleştirmede; ürün veya hizmetin özelliklerinin övülmesi ya da benzeri diğer ürün ya da hizmetlere göre belli bir ürüne yönelik tercih bildirilmesi, ürünlere veya hizmetlere özel tanıtıcı atıflar yaparak ürün veya hizmetlerin kiralanmasının veya satın alınmasının doğrudan teşvik edilmesi ve aşırı vurgu yapılması, ürüne ilişkin detaylı bilgi verilmesi ve farklı çekim teknikleriyle ürünün ön plana çıkarılması yasaktır

(4) Ürün yerleştirme ile program içerisine yerleştirilen ürün, programın bir parçasıymış gibi doğal mecrasında kullanılmalıdır.

(5) Ürün yerleştirilen programda, bir saatlik yayın süresince en fazla 4 farklı ürün yerleştirmesi yapılabilir.

(6) Ticarî iletişimi yasaklanmış ürünlerin, ürün yerleştirmede kullanılmasına izin verilmez. Ürün yerleştirme esnasında yerleştirilen ürüne ilişkin bant reklam yapılamaz.

(7) Ürün yerleştirmenin, medya hizmet sağlayıcının editöryal bağımsızlığını ve sorumluluğunu etkilemesine izin verilmez.

(8) Haber bültenlerinde, çocuk programlarında ve dinî tören yayınlarında ürün yerleştirmeye izin verilmez. 
Illgili siyasa metinlerinde bir yandan ürün yerleştirmenin yasak olduğu belirtilmiş diğer yandan ise ürün yerleştirmenin yapılabileceği programlar ve bunlara ilişkin şartlar sıralanmıştır. Burada dikkat edilmesi gereken önemli husus siyasa metinlerinin zaten daha başından kendi içlerinde çelişen bir yapıya sahip olmalarıdır. 3 Nisan 2014 tarihinde Resmi Gazete'de yayınlanarak yürürlüğe giren Yayın Hizmeti Usul ve Esasları Hakkında Yönetmelikte Değişiklik Yapılmasına Dair Yönetmelik'le ürün yerleştirme uygulamalarına niceliksel sınırlama getiren yukarıda tamamı alıntılanan 14. maddenin beşinci fıkrası endüstri temsilcisi konumundaki ticari kanalların, ajansların/yapımcıların taleplerine paralel olarak yürürlükten kalkmıştır. Ayrıca aynı maddenin birinci fıkrasına radyo yayın hizmetlerinde de ürün yerleştirme yapılabileceği hükmü eklenmiştir. ${ }^{13}$ Siyasa metninde ürün yerleştirmenin editöryal içeriğin reklamdan ayrılması ilkesine zarar vermesine izin verilmeyeceği açıkça belirtilmiş̧ir. Ancak pratikteki uygulamalara bakıldığında editöryal içerik konusunda somut sorunlar ortaya çıktığı görülmektedir.

\title{
Televizyon Drama Sektörü ve Editöryal İçerik İle İlgili Sorunlar
}

Pekçok eleştirel araştırmacı için AB'nin yeni görsel-işitsel medya siyasası, özellikle 'ürün yerleştirmeye' izin verilmesi açısından $A B$ 'nin ortak yayın siyasasının temel ilkelerine ve kültürel koruma ve çeşitlilik ile ilgili uygulamalara aykırı bir gelişmeydi (Nenova 2007; Haug 2008; Pekman 2009). GiMHD'nin siyasa oluşturma sürecinde kamu istişaresine katılan kurumlardan İngiliz kamu hizmeti yayıncısı BBC (British Broadcasting Corporation) bu konuda muhalif olanların ortak tavrını şöyle dile getirir: ${ }^{14}$

\begin{abstract}
BBC gizli reklam ile ilgili önerilen gevşeme konusunda endişelidir. Ürün yerleştirmeye izin vermek, sınıllanmış ve iyi tanımlanmış şartlarla bile olsa, içerik sağlayıcılarının içinde çalıştıkları ekonomik ve editöryal koşullarda büyük bir değişikliği gerektirecektir. Ürün yerleştirme editöryal standardlarda ve ardından da Avrupa programcılığının entegrasyonuna yönelik kamusal güvende bir düşüşe yol açar. BBC, Komisyonun bu değişiklikte ikna edici bir kanıt bulmakta başarısız olduğunu düşünmektedir.
\end{abstract}

Burada BBC'nin bahsettiği 'editöryal standartlara ilişkin kamusal güveni düşürebilecek' temel etken daha açık bir ifadeyle aslında editöryal bağımsızlığın tehlikeye girmesi ve ticari saiklerin ürün yerleştirme yoluyla editöryal içeriğe

13 Üçüncü fıkra ise şu şekilde değiştirilmiştir: Genel olarak, ürün yerleştirme, programın bütünlügünü bozmamalıdır. Ürün yerleştirmede; program içine yerleştirilen ürünlere aşırı vurgu yapılmasına izin verilmez. Program içerisine yerleştirilen ürün ve hizmetlerin tekrarlar halinde sunulması veya gösterilmesi; ürün veya hizmetin özelliklerinin övülmesi ya da benzeri diğer ürün ya da hizmetlere göre belli bir ürüne yönelik tercih bildirilmesi, ürünlere veya hizmetlere özel tanıtıcı atıflar yaparak ürün veya hizmetlerin kiralanmasının veya satın alınmasının doğrudan teşvik edilmesi, ürüne ilişkin detaylı bilgi verilmesi ve farklı çekim teknikleriyle ürünün ön plana çıkarılması yasaktır. Bkz: "Yayın Hizmeti", (www.resmigazete.gov.tr).

14 Bkz. BBC Comments on The European Commission's Issues Papers For the Liverpool Audiovisual Conference, http://ec.europa.eu/avpolicy/docs/reg/modernisation/issue_papers/contributions/ ip1 to6-bbc.pdf (Erişim tarihi: 01.01.2013). 
nüfuz etmesidir. Bizim çalışmamızda ise 'Editöryal İçerik' kavramı, TV drama sektörü açısından, senarist, yönetmen, kurgucu gibi, yapımın daha çok reklamdışı, ticari-olmayan içeriğini oluşturma amacındaki insan gücünün ortak yaratısı ve izleyicilerin de görmek için ekran karşısına geçmelerinin esas nedeni olan ürün anlamında kullanılmaktadır. Bu haliyle kavram aslında 1989 tarihli Sınırötesi Televizyon Yönergesinden beri ilgili mevzuatta bulunan ve ilk defa 2004 yılında AB mevzuatında açıkça bir ilke olarak benimsenmiş olan reklamdan ayrı içerik olarak "editöryal içerik" kavramına gönderme yapar şekilde kullanılmaktadır. ${ }^{15}$ Ayrıca kavram doğrudan habercilerin haberlerini yaparken, yayıncıların yayınlarını hazırlarken sahip olmaları gereken ve reklam-dışı içeriğe ve bu içeriğin hazırlanması sürecine gönderme yapan 'editöryal bağımsızlık'16 kavramı ile de ilişkili kullanımaktadır. Dolayısıyla BBC'nin 'editöryal standardlar" açısından yaptığı uyarının aynı burada kullanıldığı şekliyle 'editöryal içerik' için de yapılabilir.

Daha önce belirtildiği gibi Türkiye'de ürün yerleştirme uygulamalarına dair mevzuatAB mevzuatına uyumlaştııımıştır. Yayıncıların 'editöryal bağımsızlıklarının' korunması ilkesi de yukarıda alıntılanan 6112 sayılı yasanın 11. maddesinin üçüncü fıkrasıyla (bkz. [a] bendi) kâğıt üzerinde güvence altına alınmıştır. Ancak hem yasada hem de ilgili yönetmelikteki ifadeler uygulamada editöryal içeriğin ticari amaçı iletişimden ayrımı konusundaki endişelerin artmasını engellememektedir. Örneğin, yaratıcılığın en çok ön plana çıktığı, program kategorilerinden biri olan dizilerde yapılan ürün yerleştirme uygulamalarında editöryal içeriğin bağımsız biçimde hazırlanması konusunda yaratıcı kadrolar üzerinde artan baskı aslında bunun güzel bir örneğidir. Senaryo Yazarları Derneği (SENDER) başkanı İlker Barış Türkiye'de ürün yerleştirme uygulamalarından senaristlerin çoğu zaman haberdar olmadığını belirterek, "diyet yapan bir ailenin masasında bir litrelik kola görebildiklerini ya da cips yiyen diyet yapan aile" görebildiklerini belirtmektedir. Barış, senaristlerin onayı alınmaksızın yapılan ürün yerleştirme uygulamalarını, senaristlerin "manevi haklarına tecavüz" olarak nitelendirmektedir:

Bir senaryo yazarı arkadaş diziyi yazarken, dizinin bir yerinde aksiyon kısmına gelinmiş. Yapımcı arıyor diyor ki esas oğlan şu yakıt istasyonuna gidecek, yakıt

151989 tarihli Sınırötesi Televizyon Yönergesinin 10. maddesinin 1. fıkrasında 'reklamların diğer tüm içerikten ayrılmasının' bir zorunluluk olduğu belirtilmektedir. Yukarıda alıntılanın AB'nin 2004 tarihli "yorumlamalı iletişim belgesi"nde ise bir ilke olarak "editorial içerik ile reklam arasındaki ayrım"ın AB'nin görsel-işitsel ürünlere yönelik mevzuatında benimsendiği açıkça belirtilmiştir. Atıf yapılan $A B$ belgeleri için sırasıyla, bkz. http://eur-lex.europa.eu/legal-content/ EN/TXT/PDF/?uri=CELEX:31989L0552\&rid=3 ve bkz. http://eur-lex.europa.eu/legal-content/EN/ TXT/?uri=CELEX:52004XC0428\%2801\%29.

16 "Yayıncıların editoryal bağımsızlı̆̆ı" kavramlaştırması AB'nin 1989 tarihli Sınırötesi Televizyon Yönergesi'nde yer alan bir kavramlaştırmadır. bkz. http://eur-lex.europa.eu/legal-content/EN/TXT/ PDF/?uri=CELEX:31989L0552\&rid=3

Bu yasayla yayıncıların "editöryal bağımsızlığı"na açıkça atıfta bulunularak sponsor olunan programlarda ne içeriğin ne de yayın akışının yayıncı dışındaki kuruluşlarca belirlenebileceği belirtilmiştir. Ancak Kabel'in (2008) belirttiği gibi yayıncıların editöryal bağımsızlı̆ı özellikle yayıncı kuruluşların üçüncü gruplarla (ki bu ifadeyle reklam veren şirketler ve hükümet kuruluşlarının da dâhil olduğu örgütler kastetilmektedir) işbirliği nedeniyle tehdit altındadır. 
alacak. Esas oğlan evde. Bir bölüm önce arabayı evin önüne bıraktı. Peşinde adamlar vardı. Adamlar arabayı göz hapsinde tutuyorlar.[Esas Oğlan] arka kapıdan kaçıp gidecek. [Senarist] [Y]apamam demiş, TV' de bir seyretmiş, yapılmış. Esas oğlan inmiş, arabaya binmiş takip edenler de takip etmiş, yakıt almış gelmiş, niye belli değil (kişisel görüşme, 06.12.2013).

Sektördeki çetin rekabet ortamı, yayıncıların/yapımcıların ticari motivasyonu, markaların ürün yerleştirme uygulaması konusunda bilgi ve deneyim sahibi olmaması ürün yerleştirme uygulamalarının mevzuatta belirtilen ilkelere uygun yapılmasını güçleştiren faktörlerdir. 3P Product Placement Production ajansı CEO'su Mehmet Akif Ebiçlioğlu'na göre markaların ürün yerleştirme uygulamaları için büyük bütçeler ayırması ve ayırdıkları bütçelerin büyüklüğüne paralel olarak beklentilerinin ve taleplerinin artması, ürün yerleştirmenin doğasına aykırı, "hacimli uygulamalar" yapılabilmesine neden olmaktadır. Bu uygulamalar sadece yapıma zarar vermekle kalmamakta, tüketici üzerinde istenen etkiyi oluşturma açısından da başarısız olmaktadır (kişisel görüşme, 01.04. 2014).

Yukarıdaki alıntıda da açıkça ortaya çıktığı gibi yönetmenlerin ve/veya senaristlerin onayını almaksızın yapılan ürün yerleştirmeler, yapımların anlatısal bütünlüğüne zarar vermektedir. Yaratıcı emeğini ortaya koyan profesyonellerin özerklik alanlarını ortadan kaldırmaktadır. IIlker Barış'a göre, Türkiye'de ürün yerleştirme uygulamalarının yapımların bütünlügüne zarar vermeden yapılabilmesi için yurtdışındaki uygulamalara benzer şekilde, senaryo yazarları ve ajanslar arasında dramaturji bilen "ara yazarlar"ın olması gerekmektedir: "Reklamcılar, reklam yazarları dramaturji bilmiyorlar. En kısa yoldan hedefe ulaşmak amaçları. Senaryo yazarları da bunu bilmiyor. Böyle bir şeye ihtiyaç var" (kişisel görüşme, 06.12.2013). Yaptığımız görüşmelerde kanalların reklam birimleri ile içerik denetiminden sorumlu birimlerin önceliklerinin de zaman zaman çatışabildiği belirtilmiştir. Reklam birimlerinin amacı reklamvereni memnun ederek, reklam gelirlerini arttırmakken, kanalların içerik denetiminden sorumlu birimlerin önceliği RTÜK açısından sorun yaratmayacak, teknik açıdan sorunsuz içeriği yayına vermektir.

Özellikle iş güvencesi konusunda ciddi sorunların yaşandığı, çalışma koşullarını kabul etmeyen profesyonellerin işsizlik tehdidiyle karşı karşıya kaldığı bir sektörde kanalların/yapımcıların kar motivasyonu, reklamverenin isteklerini ne pahasına olursa olsun kabul etme eğilimi kanallar ve yapımcılarla yaratıcı emeğini ortaya koyanlar arasında varolan çatışmayı arttırmaktadır. Sonuçta, anlatısal bütünlüğü bozma pahasına ürün yerleştirme uygulamalarına rastlanmaktadır. Kanalların çoğu zaman yapımların tüm haklarına sahip olduğu, az sayıda büyük yapımevinin kanallarla pazarlık etme gücüne sahip olduğu sektörde, ürün yerleştirmeden elde edilen gelirin paylaşımı konusunda da sorun yaşanmaktadır. Ancak daha önce yaptıkları işlerin reytingleriyle sektörde kendini ispatlayan ve pazarlık edebilme gücüne ulaşan az sayıda oyuncu/senarist, yönetmen ürün 
yerleştirmeden elde edilen gelirden pay alabilmektedir. Diğerleri, uygulamalardan herhangi bir maddi gelir elde edememektedir:

Sözleşmelerde her türlü hakkımızı devrediyoruz. Yeni bir şey çıktığında o hakkımızı da alıyorlar. Biz bir kere para alıyoruz. Sözleşme serbestisi olduğundan, savaşamıyoruz. Ya işsiz kalıcaz... Ürün yerleştirmede de problem var. Bizim oradan maddi gelirimiz olması lazım. Bir kuruş almıyoruz. Mülk sahibi kimse o alır ürün yerleştirmeden parayı. Yapımcılar yavaş yavaş kanallarla ortak olmaya başladılar (IIlker Barış, kişisel görüşme, 06.12.2013)

Mevzuatta haber bültenlerinde, çocuk programlarında ve dini tören yayınlarında ürün yerleştirmeye izin verilemeyeceği açıkça belirtilmiştir. Ancak televizyon programlarının farklı türlere özgü öğeleri bünyesinde barındırdığı, türler arasındaki sınırların bulanıklaştığı bir dönemde (Greeber 2008: 8) programları sınıflandırma konusunda da sorun yaşanmaktadır. Bu durum pratikte, ürün yerleştirmeye dair kâğıt üzerindeki yasakların kar motivasyonu ile hareket eden ticari kanallar/yapımcılar tarafından göz ardı edilmesi riskini artıımaktadır. Yayıncılar yasal boşlukları kendi lehlerine yorumlayarak, fiili durumlar yaratabilmektedir. Bu bağlamda Ebiçlioğlu, haber bülteni olmamasına rağmen içeriğinde güncel haberlere yer veren programları örnek vererek, bu programları ürün yerleştirme açısından mezuattaki "gri alanlar"dan biri olarak nitelendirmektedir. Durumu kanallar, ajanslar, yapımcılardan oluşan endüstriyel aktörlerin bakış açısıyla değerlendiren Ebiçlioğlu bu "gri alanların" ortadan kalkmasının ürün yerleştirme uygulamalarını arttıracağını belirtmektedir (kişisel görüşme, 01.04.2014). 3 Mart 2011 tarihinden 2014 Ocak ayına kadar RTÜK ürün yerleştirme konusunda yayın kuruluşlarına yönelik toplam 21 müeyyide kararı uygulamıştır ("RTÜK Başkanı", www.rtuk.org.tr). RTÜK cezaları sınırlı tutmaya çalışarak, ürün yerleştirme uygulamalarının yaygınlaşmasını teşvik etmeye çalışmıştır:

Radyo TV Üst Kurulu genel olarak sektörün bu konuda olgunlaşmasını bekledi. Örnek oluşturucu uygulamalar, cezalar verdi. Genel anlamıyla bütün tarafların bu konuyla ilgili algısının oluşmasını, olgunlaşmasını bekleyen bir davranış ve tutum içinde. Eğer ceza vermek isteseydi... Çok fazla negatif uygulama yapıldı. (Mehmet Akif Ebiçlioğlu, 01. 04.2014).

Kâğıt üzerinde ürün yerleştirmenin esasları, gizli reklam ve ürün yerleştirme arasındaki farklar detaylı olarak belirtilmiştir. Ancak, Yayın Hizmetleri Usul ve Esasları Hakkındaki Yönetmeliğin 3. fıkrasında ürün yerleştirmede ürüne 'aşırı vurgu' yapılmasının yasaklanması, 4. fıkrasında ise ürünün hikâyenin 'doğal' bir parçasıymış gibi kullanılması gerektiği gibi yoruma açık ifadelerin yer alması uygulamada sorun yaratmaktadır. Yaptığımız görüşmelerde içerik denetiminden sorumlu profesyoneller, ürün yerleştirmeye dair mevzuattaki maddelerin yoruma çok açık olduğunu, kesin kuralların olmadığını vurgulamaktadırlar. Yoğun çalışma temposunda sezgi ve deneyimlerinden yola çıkarak, RTÜK'ün daha önce uyguladığı yaptırımları inceleyerek ve gerekirse üstlerine danışarak karar aldıklarını belirtmektedirler. Örneğin, Star TV drama yöneticisi Büke Ürküt yoğun 
çalışma temposunda, dizileri yayına yetiştirme telaşı içinde ürün yerleştirme konusunda saniyelerin, ürüne aşırı vurgu yapma gibi karışık konuların gündeme geldiğini, kritik kararların verildiğini söylerken (kişisel görüşme, 18.02. 2014) Fox TV İçerik Denetim Biriminden Nilüfer Başer ise yönetmeliği okumakla kesin yargılara ulaşılamadığını söylemektedir. Ürün yerleştirme konusunda "şu cümle söylenebilir, şu söylenemez" gibi net kuralların olmadığını belirtmektedir (kişisel görüşme, 12.02.2014).

Nilüfer Başer, yapımcıların kanallardan habersiz reklamverenle ürün yerleştirme anlaşması yapma intimaline ya da kasıtlı olmasa da gizli reklam ile ürün yerleştirme uygulamaları arasındaki ayrımın farkında olmama riskine dikkat çekmektedir (kişisel görüşme, 12.02.2014). Nitekim mevzuatın son derece yoruma açık olması, bu konuda uzmanlaşmış birimlerin bile tereddüt ettiği örneklerle karşılaşmasına neden olmaktadır. Bu durum kanalların içerik denetiminden sorumlu birimlerin risk almaktan kaçınmasına neden olmaktadır. Bu birimler RTÜK tarafından gizli reklam olarak nitelendirilebileceği endişesiyle birçok sahneyi blurlamayı, hatta atmayı tercih etmektedirler.

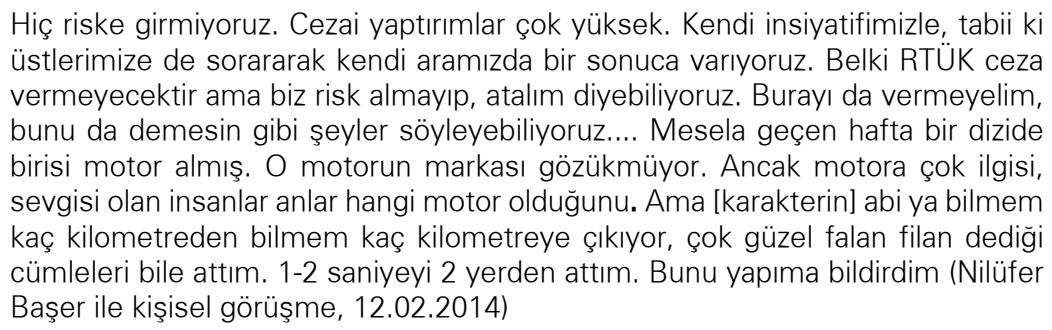

Bu durum özellikle dizilerde sorun yaratabilmektedir. RTÜK tarafından gizli reklam olarak değerlendirilebileceği düşünülen sahnelerin blurlanması, ekranda yaratılan estetik dünyaya zarar verme riski taşımaktadır. Yönetmen/senaryo yazarı Ömer Uğur'un "sokaklara çıkamıyoruz. Bir resim yapıyorsun, arkadaki emlakçı hemen buzlanıyor. Her taraf buz oluyor. Adam mantıcı dükkânı açmış. Bir isim uyduruyorsun. $O$ ismi buzluyor, uydurduğun ismi buzluyor" sözleri pratikte yaşanan sorunları anlamak açısından aydınlatıcıdır (kişisel görüşme, 29.12.2013).

Türkiye'de dizi sektöründe bir sitcom 3-4 günde çekilirken, 90 dakika uzunluğundaki, büyük prodüksiyonlu televizyon dramaları 5-6 günde çekilmektedir. Her hafta 90 ila 100 dakika uzunluğundaki bir dizi yayına yetiştirilmeye çalışılmaktadır. Senaryoların önceden hazır olmadığı, stoksuz çalışılan bir sektörde dizilerin anlatısal bütünlügüne zarar vermeyen yerleştirmelerin yapılması zorlaşmaktadır.

Hikayenin senaryosu yoksa onu [ürün yerleştirme] nereye yerleştireceksiniz. Ajansın reklamverenin senaryoyu okuması lazım. Şurda onu istiyorum burda bunu. Okumadan şimdiki gibi körleme [yapılıyor]. Bu dizi çok seyrediliyor. Kenan bilmem ne istasyonuna gitsin diyor. Stok yapan kimse yok. Altı bölüm garantiye 
alan seviniyor. Dizi [yayından] kalkarsa seyredilmeyen şeye ürün yerleştirilmiş oluyor (Illker Barış, kişisel görüşme, 06.12.2013).

Senaryolar iyice incelenmeden yapılan ürün yerleştirmeler sadece ekranda yaratılan dünyanın tutarlıı̆ına zarar vermekle kalmamakta, reklamveren açısından da başarı intimalini azaltmaktadır. Başarılı bir ürün yerleştirmede senaryo ürüne değil, ürün senaryoya uydurulmalıdır (Tığlı 2004: 44). Ürün yerleştirme uygulaması "ne yapıma zarar vermeli ne de markayı öne çıkarmalıdır" (Mehmet Akif Ebiçlioğlu, kişisel görüşme, 01.04.2014). Her hafta bir bölümü yayına yetiştirme baskısı altında çalışılan bir sektörde, fazla zaman ve emek gerektirmemesi, post prodüksiyon aşamasında yapılabilmesi gibi faktörler dijital ürün yerleştirme uygulamalarını cazip kılmaktadır. Dijital uygulamalar yapımcının onayıyla kanallar ya da ajanslar tarafından gerçekleştirilebilmektedir. Ancak zaman baskısı altında yapılan bu uygulamaların yapımın anlatısal bütünlüğüne zarar verme, yapımın teknik standartlarını düşürme riski artmaktadır:

Senaryo entegrasyona fazla girmiyoruz. Fazla emek. Senaryonun değişmesi gerek. Kanaldan birinin yapıma gitmesi, çekimi organize etmesi çok daha zor. $O$ yüzden daha çok dijital entegrasyon yapılıyor. Bilgisayar ortamında montajla yerleştiriliyor, billboard vb. Yapımcıdan da onay gerekiyor dijital entegrasyon için (Nilüfer Başer, kişisel görüşme, 12.02.2014).

Dijital entegrasyonlar post prodüksiyon aşamasında yapılan uygulamalar. Kanalların grafik ekipleri oluyor. Yapımcı tarafından hazırlanan kasetler genelde yayına çok kısa bir süre kala geliyor. O süreci yönetmek için yayıncı tarafından çözüm üretiliyor. Yapım çekilirken, billboard"lar belirleniyor.illetişimi yapılacak markanın görseli hazırlanıyor. Bunlar yayıncıda duruyor.Yapımcıdan kaset geldiğinde daha önce belirlenmiş billboard"lara uygulama yapılıyor. [Dijital entegrasyonu] [s]adece yayıncılar yapıyor diye bir şey söz konusu değil. Biz de[ajanslar] cevap oluyoruz. Diziler portallarde de yayınlanıyor. Portallerde yaptığımız uygulamalar da var. Etkin dijital entegrasyon yapabilmek için dramatik etkiyi de düşünmeli. Teknik kabiliyet de önemli. Dijital entegrasyonlarda hıza dayalı eksiklikler, teknik kabiliyet yoksunluğundan [kaynaklanan] problemler görüldü (Mehmet Akif Ebiçlioğlu, kişisel görüşme, 01.04.2014)

\section{Sinema Oyuncuları Meslek Birliği (BiROY) Başkanı Janset Paçal} Türkiye'de ürün yerleştirme uygulamalarına yeterince emek harcanmadığını belirterek, oyuncunun karakterden çıkıp reklam karakterine büründürüldüğünü söylemektedir:

Ürün yerleştirme görgüsüzce yapılıyor. Oyuncu karakterden çıkıyor, reklam karakterine bürünüyor. Çirkin yapılıyor. Hangi reklamı aldıysan senaryoya yedirilmeli. O da zaman ve emek istiyor. Bizde reklam spotu oyuncunun ağzına yapıştırılıyor. Oyuncu para alıyor mu belli değil. Ağzına o kadar çirkin replik yapıştırıyorlarsa umarım karşılığını veriyorlardır (Janset Paçal, kişisel görüşme, 29.11.2013). 
Özellikle diziler örneğinde ürün yerleştirme uygulamaları ve ticari kaygılar anlatısal bütünlüğe, karakter gelişimine zarar verebilmektedir. Ekranda yaratılan kurgusal dünyaların bütünlügünü bozabilmektedir. Ayrıca sektörün telif, çalışma koşulları konularındaki yapısal sorunları pratikte ürün yerleştirme uygulamalarında da sorun yaşanma riskini arttırmaktadır.

\section{Sonuç}

Yeni bir tekno-ekonomik paradigmanın ortaya çıkardığı mevcut ticari rekabet ortamında ürün yerleştirmenin artan oranda başvurulan bir reklam tekniği olması ticari kaygılar göz önüne alındığında hiç de şaşılacak bir durum yaratmamaktadır. Ayrıca serbest piyasa mekanizmalarının belirleyici olduğu mevcut iletişim endüstrisinde verimlilik ve kar yapma saikleri ile sanatsal/ editöryal amaçlar arasında çatışma olacağı da aynı derecede öngörülebilir bir durumdur. Bu gerçeğe rağmen, aralarında BBC gibi önde gelen kamu hizmeti yayıncısı kuruluşlarının da olduğu bir takım örgütlerin editöryal içerik ile ilgili itirazları ürün yerleştirmeye izin verilmesi konusunda karar verici konumda olanlar tarafından dikkate alınmamış ve içerik ile reklam arasında ayrım ilkesi mevzuatta söylemsel olarak yer almanın ötesine gitmemiştir. Bu durum ürün yerleştirmeye dair siyasa oluşturma sürecinde $A B^{\prime}$ nin kültürel kaygılardan ziyade ekonomik kaygılarla hareket ettiğini ortaya koymaktadır. $A B$ ile pek çok konuda görüş ayrılığı yaşanırken, ürün yerleştirme konusundaki sektörün ticari kaygılarının azaltılmasına fayda sağlayan bu tür düzenlemeler Türkiye'de de neredeyse tamamen aynı şekilde yürürlüğe sokulmuştur.

Kanal ve yapımcıların neredeyse tamamen kar motivasyonu ile hareket ettiği, emekçilerinin ise sürekli bir güvencesizlik sorunuyla karşı karşıya kaldığı Türkiye'de, televizyon sektöründe reklam verenlerin isteklerinin her şekilde karşılandığı bir yapı ortaya çıkmaktadır. Türkiye'deki dizi sektörünün uzun çalışma saatleri, 'stoksuz' çalışma zorunluluğu gibi kendine has sorunları da bunlara eklenince pratikte kültürle ve yaratıcılıkla ilgili kaygıların arka planda kalma riski artmaktadır. Kısıtlı zaman ve daha fazla kazanç baskısı altında yapılan ürün yerleştirme uygulamaları, yapımların anlatısal bütünlüklerine zarar vermekte ve teknik standartlarını düşürebilmektedir. Nitekim çalışmamızda görüşlerine yer verdiğimiz görüşmeciler de bu yönde bilgiler aktarmışlardır.

Bununla birlikte, çalışmamız metin (diziler, filmler, TV programları vb.) düzeyinde, metnin üretim süreci ve koşulları ile yaratımsal süreç arasındaki artan gerilime odaklanmaktadır. Ancak metinlerin üretimi kadar tüketim/alımlanma boyutunun da dikkate alınması gerekmektedir. Bu açıdan ürün yerleştirmenin izleyici gruplarının izleme edimleri üzerindeki etkileri konusunda yapılacak bilimsel araştırmalara ciddi bir intiyaç olduğunun altı çizilmelidir. Örneğin mevzuatta vurgulanan bir husus olan ürün yerleştirmenin özellikle senaryonun doğal akışı içine yedirilmesi gerekliliğinin izleyicinin reklamı farketmesini zorlaştırıp zorlaştırmadığı ve bu anlamda da 'gizli' reklam haline gelmesine 
neden olacak bir durumun ortaya çıkmasına neden olup olmadığı sorusu bilimsel araştırmalara dayanarak yanıtlanmalıdır. Bu anlamda farklı ürün yerleştirme uygulamalarının izleyici/yurttaşlarca nasıl algılandığı ve alımlandığını anlamak ve açıklamak gerekmektedir. Bundan sonra yapılacak çalışmaların özellikle tüketim/ alımlama boyutu üzerinde yoğunlaşması hem siyasa yapıcılar açısından hem de sektördekiler açısından önemli bir bilgi boşluğunun dolmasına ve böylece daha doğru karar alma süreçlerinin ortaya çıkmasına yardımcı olacaktır.

\section{Kaynakça}

ARGAN Metin, NURTANIŞ VELIOĞLU Meltem ve TOKAY ARGAN Mehpare (2007), "Marka Yerleştirme Stratejilerinin Hatırlama Üzerine Etkisi: 'GORA' Filmi Üzerine Araştırma", Elektronik Sosyal Bilimler Dergisi, 16 (19), ss. 159-178.

BALASUBRAMANIAN Siva K., KARRH James A. ve PATWARDHAN Hemant (2006), "Audience Response To Product Placements: An Integrative Framework and Future Research Agenda", Journal of Advertising, 35(3), ss. 115-141.

BALASUBRAMANIAN Siva K. (1994), "Beyond Advertising and Publicity: Hybrid messages and Public Policy Issues", Journal of Advertising, 23(4), ss. 29-46.

BEK Mine Gencel (2003), “Avrupa Birliği'nde Illetişim Alanının Düzenlenmesi: Kültür Ağırlıkı Politikadan Ekonomi Merkezli Politikaya Doğru", Avrupa Birliği ve Türkiye'de İletişim Politikaları içinde, der. Mine Gencel Bek, Ankara: Ümit, ss. 23-59.

BiR Ali Atıf "TV'de ürün yerleştirmeye evet ama yetmez", Bugün, http:// www.bugun.com.tr/tvde-urun-yerlestirmeye-evet-ama-yetmez-yazisi-192970 (20.05.2012) (Erişim tarihi: 03.20.2014)

BUSS Dale (1998) "Product Placement Hall of Fame", BusinessWeek, http:// www. businessweek.com/1998/25/b3583062.htm (Erişim tarihi: 10.10.2014)

CHANDLER Daniel ve MUNDAY Rod (2011), A Dictionary of Media and Communication, Oxford: Oxford University Press.

ÇELIKCAN Peyami, "2013 Yılı Reklam Verileriyle Türkiye Radyo ve Televizyon Yayıncılığı Sektör Raporu", http://www.ratem.org/web/RATEM_Sektor_ Raporu_2014.pdf (Erişim tarihi: 17.10.2014)

ECKERT Charles (1978), "The Carole Lombard in Macy's Window", Quarterly Review of Film Studies, 3(1), ss.1-21.

GINOSAR Avshalom (2012), "Change and Divergence in Regulatory Regimes: A Comparative Study of Product Placement Regulation", Trends in Communication Policy Research içinde, der. Natacsha Just ve Manuel Puppis, Bristol \&Chicago: Intellect, ss. 95-117. 
GOULD Stephen, GUPTA Pola ve GRABNER-KRÄUTER Sonja (2000), “Product Placements in Movies: A Cross-Cultural Analysis of Austrian, French and American Consumers' Attitudes toward This Emerging, International Promotional Medium", Journal of Advertising, 29: 4, ss. 41-58.

HACKLEY Chris, TIWSAKUL Rungpaka Amy ve PREUSS Lutz (2008), "An ethical evaluation of product placement: a deceptive practice?", Business Ethics: A European Review 17(2), ss. 109-120.

HAUG Thomas Walter (2008), “The New Audiovisual media Services Directive as a Missed Opportunity in view of the Protection of Children and Young People Against Harmful Influences of Advertisement in Nowadays' Media", European Law, 4: 1, ss. 35-41.

KABEL Jan (2008), "Sponsorship", European Media Law içinde, der. Oliver Castendyk, E. J. Dommering, Alexander Scheuer; Kluwer Law International, Hollanda, ss. 619-640.

MATTELART Armand (2001), İletişimin Dünyasallaşması, Çev. Halime Yücel, İstanbul: İletişim.

MILLER Mark Crispin (2004), "Hollywood The Ad", Hollywood: Cultural Dimensions: Ideology, Identity and Cultural Industry Studies içinde, der. Thomas Schatz, London \&New York, ss.280-312.

MORRIS James (2011), “How European Media Companies Are Dealing With Product Placement", http://adage.com/article/global-news/european-mediacompanies-dealing-product-placement/228121/ (Erişim tarihi: 15.03.2014)

NENOVA Mira Burri (2007), "The Reform of the European Community Audiovisual Media Regulation: Television Without Cultural Diversity", International Journal of Cultural Property, 14: ss. 169-204.

NEWELL Jay, SALMON Charles T. ve CHANG, Susan (2006), "The Hidden History of Product Placement", Journal of Broadcasting and Electronic Media, 50:4: ss. 575-594.

PEKMAN, Cem (1997), Televizyonda Özelleştirme, İstanbul: Beta.

PEKMAN Cem (2001), "Çokuluslu Reklamcılık, Uluslarası Düzenlemeler ve Ulusal Uygulamalar: Kuralları Kim İster?", Medya Politikaları içinde, der. Beybin Kejanlıoğlu, Sevilay Çelenk ve Gülseren Adaklı, Ankara: İmge, ss. 205-243.

PEKMAN Cem (2009), "AB'de Medya Okuryazarlığının Sonu: Ürün Yerleştirme”, Medya ve Kültür- Karaelmas 2009 içinde, der. Nurçay Türkoğlu ve Sevilen Toprak Alayoğlu, İstanbul: Urban, ss. 569-576.

PEKMAN Cem, TÜZÜN Selin (2008), "Product Placement in Late Turkish Cinema", 6. Uluslarası Communication In the Millennium Sempozyumu, İstanbul Üniversitesi, ss. 339-347. 
TAŞDEMiR, Babacan (2014), (The) Concept of "Information Society" As the Basis of EU's "New" Media Policy: A Critical Appraisal, ODTÜ SBE Bilim ve Teknoloji Politikası Çalışmaları ABD, Yayınlanmamış Doktora Tezi, Ankara TIĞLI Mehmet (2004), Bir Aktör Olarak Markalar, İstanbul: Türkmen.

TURNER Graeme (2008), "Genre, Hybridity and Mutation", The Television Genre Book içinde, der. G. Creeber, New York: Palgrave Macmillan, s.8.

TÜZÜN Selin (2013), “Multipleks Sinema Salonları ve Türkiye Örneğinde Sinema Sektöründe Değişen Güç Dengeleri", Sinecine, 4(1), ss. 85-115.

WASKO Janet (2003), How Hollywood Works, London: Sage.

\section{Internet Erişimi}

KARA Meltem, "Dizi ve Filmler 'ihracat' sayılacak Türk malı ekranda 'buz'lanmayacak", Hürriyet, http://www.hurriyet.com.tr/ekonomi/14310692. asp (Erişim tarihi: 03.03.2014)

O'REILLY Lara, "Ofcom product placement logo unveiled", MarketingWeek, 14.02.2011, http://www.marketingweek.co.uk/ofcom-product-placement-logounveiled/3023394.article (Erişim tarihi: 15.02.2014).

"Avrupa Birliği Görsel İşitsel Medya Hizmetleri Yönergesi", http://www.rtuk.gov. tr/\#, (Erişim tarihi: 09.10.2014)

"BBC Comments on The European Commission's Issues Papers For the Liverpool Audiovisual Conference", http://ec.europa.eu/archives/information_ society/avpolicy/docs/reg/modernisation/issue_papers/contributions/ip1 to6-bbc. pdf (Erişim tarihi: 19.10.2014).

"Commission interpretative communication on certain aspects of the provisions on televised advertising in the 'Television without frontiers' " Directive (2004/C 102/02), www.euromedaudiovisuel.net (Erişim tarihi: 02.02.2012).

"En Çok Ürün Yerleştirme Yapılan Dizi 'Kuzey Güney'". http://www. connectedvivaki.com/en-cok-urun-yerlestirme-yapilan-dizi-kuzey-guneyinfografik/ (2012, 14 Şubat) (Erişim tarihi: 21.03.2014)

"Global Product Placement Spending Up 10\% to \$7.4 Billion in 2011, Pacing for $11 \%$ Growth in 2012, as Wireless Technology, Changing Consumer Habits \& Looser Regulations Compel Brands to Invest in Alternative Marketing Solutions" http://www.pqmedia.com/about-press-201212.html (Erişim tarihi: 21.03.2014)

"Medya Yatırımları", http://rd.org.tr/doc/10-yillik-reklam-yatirimi-toplami.pdf (Erişim tarihi: 20.03.2014)

"New TV and product Placement rules should be applied before end 2009", http://www.europarl.europa.eu/sides/getDoc.do?language=en\&type=IM-PRES S\&reference=20071128IPR14028 (Erişim tarihi: 15.03.2014). 
"Reklam Pazarı 5 milyara koşuyor", Sabah, http://www.sabah.com.tr/ Ekonomi/2013/03/14/reklam-pazari-5-milyara-kosuyor (Erişim tarihi: 05.03.2014).

“RTÜK Başkanı Prof. Dr. Davut Dursun: Ürün yerleştirme, kavram ve uygulama olarak Türkiye'nin yeni tanıştığı bir alan", http://www.rtuk.org.tr/sayfalar/ IcerikGoster.aspx?icerik_id=cad91943-29c1-4c36-9f4c-708ba4941c74 (Erişim tarihi: 03.03.2014)

"SEYAP Film ve TV Dizilerine Ürün Yerleştirme Uygulamasını Destekliyor", http://www.kilimfilim.com/2010/01/seyap-film-ve-tv-dizilerine-urun.html (Erişim tarihi: 01.03.2014).

"Televizyon İzleme Eğilimleri Araştırması 2012", http://rtuk.org.tr/lcerik/ DownloadReport/13 (Erişim tarihi: 20.10.2014).

"Ürün Yerleştirme Çalışmaları Artıyor", http://www.capital.com.tr/urunyerlestirme-calismalari-artiyor-haberler/24198.aspx (Erişim Tarihi: 03.03.2014).

"Yayın Hizmeti Usul ve Esasları Hakkında Yönetmelik", http://www.rtuk.org. tr/sayfalar/IcerikGoster.aspx?icerik_id=d1357d3f-cb56-47db-8e6f-f2d8bfdf144f (Erişim tarihi: 01.01.2013)

"Yayın Hizmeti Usul ve Esasları Hakkında Yönetmelikte Değişiklik Yapılmasına Dair Yönetmelik", http://www.resmigazete.gov.tr/eskiler/2014/04/20140403-1. htm (Erişim Tarihi: 20.04.2014).

“6112 Sayılı Radyo ve Televizyonların Kuruluş ve Yayın Hizmetleri Hakkında Kanun", http://www.rtuk.org.tr/sayfalar/lcerikGoster.aspx?icerik_id=5a3cac1eb6d9-4b23-bc7a-8dcd671fceba (Erişim tarihi: 02.06.2013)

\section{Kişisel Görüşmeler}

BARIŞ IIlker, Senaryo Yazarları Derneği (SENDER) Başkanı, Selin Tüzün ile kişisel görüşme, İstanbul, 06.12.2014

BAŞER Nilüfer, Program Departmanı İçerik Denetim Asistanı, Selin Tüzün ile kişisel görüşme, İstanbul, 12.02.2014

DEMiR İlyas, Medya Planlamacı, Starcom,İstanbul, 06.07.2012

EBiÇLiOĞLU Akif Mehmet, 3P Product Placement Production Ajansı CEO, Selin Tüzün ile kişisel görüşme, İstanbul, 01.04.2014

UĞUR Ömer, Yönetmen/Senaryo Yazarı, Selin Tüzün ile kişisel görüşme, İstanbul, 29.12.2013

ÜRKÜT Büke, Star TV Drama Birimi Yöneticisi, Selin Tüzün ile kişisel görüşme, İstanbul, 18.02.2014

PAÇAL Janset, Sinema Oyuncuları Meslek Birliği (BiROY) Başkanı, Selin Tüzün ile kişisel görüşme, İstanbul, 29.11.2013 


\section{Ek 1:}

\begin{tabular}{|l|l|}
\hline $\begin{array}{l}\text { Ocak } 2014 \\
\text { Ürün Yerleştirme }\end{array}$ \\
\hline Ana Sektör & Süre \\
\hline Gıda (G) & 5,787 \\
\hline Elektronik Ev Eşyaları (Eee) & 2,541 \\
\hline Inş̧aat ve Dekorasyon Hizmetleri (Idh) & 1,913 \\
\hline Mobilya, Ev Tekstili ve Eşyaları (Mete) & 1,912 \\
\hline Bilgi Teknolojileri (Bt) & 1,378 \\
\hline Tekstil (T) & 655 \\
\hline Optik-Saat-Aksesuar (Osa) & 476 \\
\hline Otomotiv, Ulaşım Araçları ve Yan Sanayii (Ouays) & 446 \\
\hline Perakendecilik (P) & 343 \\
\hline Yayıncılık (Y) & 224 \\
\hline
\end{tabular}

\begin{tabular}{|l|l|}
\hline $\begin{array}{l}\text { Ocak } 2014 \\
\text { Ürün Yerleştirme }\end{array}$ & Süre \\
\hline Reklamın Firması & 4,251 \\
\hline Küçükbay Yağ Sanayi A.Ş. & 2,490 \\
\hline Profilo Holding & 1,328 \\
\hline Akçalı Boya Ve Kimya Sanayi Ticaret A.Ş. & 1,193 \\
\hline Doğtaş Mob. Dekorasyon & 846 \\
\hline Filiz Gıda Sanayii & 713 \\
\hline Vestel & 573 \\
\hline Casper Bilgisayar Sistemleri A.Ş. & 479 \\
\hline Marshall Boya A.Ş. & 463 \\
\hline Özdilek A.Ş. & 378 \\
\hline Triko Mısırlı San. Tic. & \\
\hline
\end{tabular}




\begin{tabular}{|l|l|}
\hline \begin{tabular}{l} 
Ocak 2014 Ürün Yerleştirme \\
\hline Medya
\end{tabular} & Süre \\
\hline Kanal D & 6,220 \\
\hline Stv & 5,025 \\
\hline Kanal Türk & 2,400 \\
\hline Show & 846 \\
\hline Tv8 & 713 \\
\hline Star & 694 \\
\hline Atv & 92 \\
\hline Ntv & 29 \\
\hline Cnn Türk & 8 \\
\hline Fox & 5 \\
\hline & \\
\hline
\end{tabular}

\begin{tabular}{|l|l|}
\hline $\begin{array}{l}\text { Ocak } 2014 \\
\text { Ürün Yerleştirme }\end{array}$ \\
\hline prBrand & Süre \\
\hline Orkide & 4,251 \\
\hline Profilo & 2,490 \\
\hline Akçalı Boya & 1,328 \\
\hline Doğtaş & 1,193 \\
\hline Vestel & 713 \\
\hline Casper & 573 \\
\hline Marshall & 479 \\
\hline Filiz Gıda & 471 \\
\hline Özdilek & 463 \\
\hline Triko Mısırlı & 378 \\
\hline
\end{tabular}




\begin{tabular}{|l|l|}
\hline $\begin{array}{l}\text { Ocak } 2014 \\
\text { Ürün Yerleştirme }\end{array}$ & Süre \\
\hline Program - Yapım & 5,212 \\
\hline Kaynana Gelin Seda'ya Gelin (Yarisma) & 4,679 \\
\hline Yeşil Elma & 2,256 \\
\hline Muhabbet Olsun & 713 \\
\hline Saba Tümer'le Bu Gece (Sohbet) & 703 \\
\hline Gülben (Eglence) & 557 \\
\hline Evim Şahane (Kadin) & 328 \\
\hline Medcezir (Yerli Dizi) & 287 \\
\hline İi Dünya Arasında (Yerli Dizi) & 144 \\
\hline Emel Acar ile Yeniden & 144 \\
\hline Yalan Dünya (Yerli Dizi) & \\
\hline
\end{tabular}

\begin{tabular}{|l|l|}
\hline \multicolumn{2}{|l|}{ Ocak 2014} \\
Ürün Yerleştirme \\
\hline Spot Tipi & Süre \\
\hline Hediye-Ürün Tan. Ürün Yer. & 6,104 \\
\hline Pasif Ürün Yer. & 5,412 \\
\hline Aktif Ürün Yer. & 3,739 \\
\hline Dijital Ürün Yer. & 521 \\
\hline Seneryo Ent. Ürün Yer. & 221 \\
\hline Sesli Ürün Yer. & 35 \\
\hline
\end{tabular}

Kaynak: Nielsen Medya

( S.Tüzün ile kişisel e-posta görüşmesi, 12 Mart 2014) 